\title{
The Effectiveness of Using Dramatic Problematizer Language Learning Model in Developing EFL Prospective Teachers' Critical Reading Skills and Reading Habits
}

\section{Dr. Hasnaa Sabry Abdel-Hamid Ahmed Helwa} Assistant Professor at Department of Curriculum and TEFL Instruction - Faculty of Education- Benha University- Egypt

\section{Abstract}

7 The study aimed to investigate the effectiveness of using dramatic problematizer language learning model in developing EFL prospective teachers' critical reading skills and reading habits. The design of the study was a mixed research methodology. It combined both quantitative and qualitative methods of collecting data. The participants of the study consisted of sixty students $(N=60)$. They were chosen from third students enrolled in English section at Benha Faculty of Education, Egypt. They were divided into two groups; an experimental group $(N=30)$ and a control group $(N=30)$. The experimental group was taught through using Dramatic Problematizer Language Learning Model, while the control group was taught by the regular method. Both groups were tested before and after the treatment. The instruments of the study included an EFL critical reading skills test, an EFL reading habits scale and semi-structured interview. Results of the study revealed a statistically significant difference between the mean scores of the control group and experimental group students in the pre and post administration of the EFL critical reading skills and reading habits in favor of the experimental group. These results were ascribed to using dramatic problematizer language learning model.

Keywords: Dramatic Problematizer language learning Model -EFL Critical Reading Skills - Reading Habits

\section{Introduction}

Today, we live in an age where knowledge is not only a means but an end in itself. We live in a generation of digital revolution and use information and communication technologies (ICTs) and the Internet every day. Technology 
plays an important role in people's lives especially college students. 21st century skills refers to the set of skills needed to succeed and work in the 21st century such as learning and innovation skills (creative skills, critical thinking skills, problem solving, communication and collaboration skills), information and communication technology skills (information culture, media culture, and technological culture), and life and work skills (flexibility, adaptation, initiative, self-direction, social skills, productivity and accountability, leadership and responsibility).

Reading is an important activity in the process of learning .It is a process of thinking, evaluating, judging, imagining, reasoning and problem solving .It is the identification of the symbols and the association of appropriate meaning with them. It requires identification and comprehension (Palani, 2012).Therefore, it is considered a complex term that encompasses different types, process and skills of reading. Thus, Hudson (2007) cited in Tanaka (2015) divides reading skills into four groups: word-attack skills, comprehension skills, fluency skills and critical reading skills. He defines reading as it provides the reader with the skills to analyze, synthesize, and evaluate what is read, and states that this process involves activities such as seeing the cause and effect or comparison relationships in the text, or adopting a critical stance toward the text.

Küçükoğlu (2013) clarified that reading is considered one of the most important skills in English Language teaching (ELT) classrooms. Being a good reader is one of the key elements to success not only in academic areas, but also in social lives. Thus, critical reading (CR) refers to questioning and assessing what we read. As we cannot evaluate something we do not understand. Thus, understanding what we read is the key point for critical 
evaluation. The reader tries to find out the strengths and weaknesses in the reading text. In the last decades reading skill is no longer considered as a passive activity. The reader is expected to interact with the text and try to construct his/her own meaning out of what $s /$ he reads.

Critical reading is a meta-cognitive process, in which the reader interacts with texts, asks questions and makes predictions and connections via prior knowledge and experiences. It is active reading that requires an activity on the part of the learner. It suggests more than the ability to understand the explicit meaning of the passage. It also involves application, analysis, evaluation and imagination. It is an analytical process that requires reading in depth and active, asking questions about text, developing hypotheses and judgments. CR plays an important role in individuals' accepting author's arguments by wondering, questioning, criticizing, investigating from reliable sources, using the mind and selfcriticism in distinguishing the facts, making judgments by making inferences, in understanding and interpreting themselves and the world, instead of accepting outside information or author's point of view directly (Haromi, 2014, Karabay , 2015,Karaca \& Oguz, 2017 ).

Critical reading originally comes from the concept of critical thinking. It is the application of critical thinking in the process of reading. In CR, readers actively try to discover information and ideas within the text. It is done by analyzing, synthesizing, drawing inference, forming interpretations and evaluating what they read. Thus, CR is an activity of reading that applies the concept of critical thinking. The readers attempt to read using analytical ways, so they understand the message of the text, the language used in the text, and the arrangement of the text. In addition, critical readers can respond to the writers' position and purpose based on different point of view related to their previous knowledge of the text (Lestari, 2015). 
The main concern in CR is helping students understand the text critically like reading between the lines or reading for deeper meaning because if teachers could help them to develop CR skills, they would definitely have good reading comprehension skills and could be successful. Students with good reading comprehension skills could perform well in any subject/course because they have developed the CR skills to not only understand but analyze any text given to them (Abd Kadir, Subki, Jamal \& Ismail, 2014).

Tomasek (2009) clarifies that students can critically read in a variety of ways: when they raise vital questions and problems from the text; when they gather and assess relevant information and then offer interpretations of that information; when they test their interpretations against previous knowledge or experience and current experience; when they examine their assumptions and the implications of those assumptions, and when they use what they have read to communicate effectively with others or to develop potential solutions to complex problems.

Critical reading can help enhance critical language awareness. It makes readers recognize, detect, respond to and connect the ideological purposes of diction used by the author of a given context. It can be perceived as a process in which readers, text, and writers interact with each other. Therefore, Wallace (1998) states that there are three purposes of CR: linguistic, critical conceptual, and cultural. From the linguistic aspect, CR aims to involve readers in texts so that they can identify ideological messages delivered by the texts. From the critical conceptual point of view, CR provides readers with an opportunity to develop convincing arguments, connect their knowledge with the social context, and question the content to construct knowledge. In cultural perspective, CR is believed to 
give a chance to the readers to enrich their knowledge by understanding different cultures from different points of view.

Ulu, Avşar-Tuncay \& Baş (2017) state that CR is a type of reading that based on acquiring high-level information rather than basic information. Sriwantaneeyakul (2018) indicates that underlying or between the line meanings need more advanced reading skill that is CR. Nasrollahi, Krishnasam \& Noor (2015) clarify that CR is an interactive process that uses several levels of thought simultaneously and critical readers are asking questions about the text they are reading. In addition, Damaianti, Damaianti \& Mulyati (2017) clarify that critical readers should be active readers asking questions, looking for facts, and suspending judgment until they assume right . Abd Kadir, Subki, Jamal\& Ismail (2014) indicate that CR skills as the skills that help students to analyze, synthesize, and evaluate what is read. However, in order for students to acquire these skills, they need to be exposed and taught how to be critical readers.

$\mathrm{Yu}$ (2015) clarifies that CR is not simply careful and detailed reading. To read critically, one must actively recognize and analyze information hel she reads on the text. Textbooks on CR commonly ask students to accomplish certain goals in reading, such as; understanding why the author writes this and the important information in the text, analyzing and summarizing. Thus, in order to read critically, readers need to read between the lines. When the students finish reading, the teacher asks them to design questions themselves to help achieve further comprehension. Each designs his own questions and they ask each other to try to understand the text deeper. 
Critical reading skills could help students become better readers and thinkers because they will be looking at reading as a process rather than a product. It is the ability to evaluate the effectiveness of writing. All writers have a purpose when they write, and they emphasize facts or details that support their purpose and ignore facts that do not. Thus, it can be found that textbooks on critical reading ask students to recognize an author's purpose, understand tone and persuasive elements and recognize bias (Abdel Halim, 2011).

Anuar \& Sidhu (2017) indicate that critical readers should have the ability to evaluate and conclude the value of a text by looking into the arguments and evaluating the evidence provided. The ability to read critically is essential for students because they possess good critical reading skills that help them to go beyond the information given by asking questions, making hypotheses, seeking evidence, and validating assumptions. Therefore, students exposed to CR skills have the ability to identify and synthesize the information.

It can be concluded that, CR is an area which has been the center of attention of critical pedagogues for many years. It suggests relating the learning experience to the students' own realities, which affects text selection, student involvement and classroom communication. In other words, CR aims at providing an environment for genuine two-way communication in the classroom, where the students can teach the teacher as much as the opposite (IÇMEZ, 2009, Zabihi \& Pordel, 2011).

Hudson (2007) cited in Abd Kadir, Subki, Jamal \& Ismail (2014) indicates that teachers need to teach CR skills to students because they want them to not only know how to convert orthographic symbols to language (word attack skills), use context and knowledge to comprehend what is 
read (comprehension skills), or see larger sentences as wholes, a process which help students to read fluently (fluency skills).Maltepe (2016) clarify that CR refers to individuals' thinking about what they read, assessing what they have read, and using their own judgment about what they have read. Thus, in order to teach CR skills to students, a teacher is expected to have knowledge about text selection, use of appropriate methods, preparation of functional learning and teaching processes, among other qualities; teachers must display CR skills as well. NematTabrizi \& Saber (2016) stated that CR involves bringing outside knowledge and values to evaluate the presentation of the text and decide what to accept as true.

Anuar \& Sidhu (2017) clarified that CR is a challenging skill. It is not only limited to understanding the text, but also to determine accuracy of facts and its interpretations through the process of assessing the opinions or knowledge. It is defined as the ability to make judgments and inferences, distinguish between facts and opinion and recognize the author's purpose or points of view. Therefore, Abd Kadir, Subki, Jamal \& Ismail (2014) confirm that students would be able to analyze, synthesize and evaluate information in the text easily if they acquire critical reading skills from an early stage.

It can be noted that reading is considered as an activity oriented skill. It involves the mechanics of the brain and the combination of other organs before comprehension occurs. This activity becomes a habit when it is frequently carried out. Reading habits enhance the promotion of one's personal development and social progresses in general .They depend on a large extent on parent's attitudes, efforts and home circumstances. Parental contribution is an important part of developing reading habits among students. Thus, in reading habits the person 
perceives reading as a need (Florence, Adesola, Alaba \& Adewumi, 2017, Adnan, Akram \& Akram, 2016, Erkan, Dağal \& Tezcan, 2016).

Moreover, reading is crucial to investigate colleges of Education students reading habits and how to improve the skill. In colleges, success is connected to reading. To obtain the required points, students are required to master all the courses taken. Students are expected to read, so as to get the expected grade point. Achievement in the colleges requires awareness of facts and acquisition of skills. All these can be acquired through reading. The habit of reading does not reflect in the lives of most students in colleges and universities. It is believed that a college learner knows how to read, what to read, when to read and where to read. The assumption states that students must have a book to read at a particular time, whether for pleasure or to pass examination. Reading habit means an individual's constant reading in a critical manner, as a result of his $\backslash$ her considering this activity as a need to be met and a source of pleasure (Florence, Adesola, Alaba\& Adewumi, 2017, Oguz, Yıldız \& Hayırsever, 2009).

Owusu-Acheaw (2014) indicates that reading makes way for a better understanding of one's own experiences and it can be an essential way for self-discovery. Thus, reading habits determine the academic achievements of students to a great extent. Both reading and academic achievements are interrelated and dependent on each other. While some students have good reading habits, others tend to exhibit poor reading habits. Reading habits can affect the personality of individuals and help them to improve their thinking methods, and create new ideas.

Reading habits are the intellectual activities for giving more information, knowledge and learn to various types of things and their activities. They means behavior which express the 
lightness of reading of individual, which occur regularly of leisure reading approach, type of reading and use of library services. Reading habit is an active skill based process of constructing meaning and gaining knowledge from oral, visual and written text. A good reading habit is necessary for a healthy intellectual growth and plays an essential role in enabling a person to achieve practical efficiency. Therefore, the results conducted by Babu \& Durgaiah (2016) and Durgaiah (2016) revealed that there was a significant difference in reading habits in relation to their age, management, gender and qualification among student teachers. Thus, a good reading habit is necessary for a healthy intellectual growth and plays a very crucial role in enabling a person to achieve practical efficiency.

Adnan, Akram \& Akram (2016) \& Hopper (2005) indicate that reading habits of youth are diminishing nowadays and the reason behind this fact are television, cell phones, videos, computer games and other negative ways of entertainment which play a contributory role to such worsen situation. The reading habits of individuals are being influenced by their personal, social, educational, economical and occupational backgrounds. Oguz, Yıldız \& Hayırsever (2009) investigate the level of reading habit of future classroom teachers, to discuss the obtained results according to their socio-demographic features and define the factors that are influential on taking up reading in the context of future teachers' experiences. The sample of the study consists of the fourth grade students from seven faculties of education.

Siebert (2008) cited in Adnan, Akram \& Akram (2016) identifies that there are three ways used for developing good reading habits such as: set up a schedule for studying ;a student who makes better use of his time to read regularly proves to be a successful reader with comparison 
to other students who do not screen their time to read. If someone waits for exams to study then his views would not be as clear as a student who read regularly according to a schedule. It is important to assign specific time, duration and breaks during study. This process restores concentration to study again. Find a place to study; suitable place is necessary for better reading. Find a place without any kind of noise, disruption and interruption. Some people have a habit to read while watching TV or listening music but majority of people like to read in a peaceful atmosphere. It can be useful to find out such a peaceful place for study. Reward your studying; it is difficult to make a routine for study. It is a long term process to make a habit of reading. At first, one should motivate oneself for some kind of reward after reading a book. It helps you for further study. After motivation, set goals to read and read until it becomes a strong habit.

Chiang (2016) clarifies that the development of reading habits for English-language materials takes a long time and good reading habits have impacts on the effectiveness of language learning. Thus in his study, he validates the influence of reading habits on language learning achievements by using principles for deep knowledge as the mediating variable.In his study, Bulgurcuoglu (2016) confirmed that there is a positive and significant correlation between critical thinking and reading habit of pre-service physical education teachers. As reading habit levels of pre-service teachers increase their critical thinking levels increase accordingly.

When reading, which is the basic way to access knowledge, becomes a habit, the concept of reading habit occurs. Reading habit is defined as individuals' realizing the act of reading in a life-long, constant, regular and critical manner, as a result of reading .It is an intellectual 
activity for giving more information, knowledge and learn to various types of things and their activities. Thus, it is an important to construct in reading research as it serves as a significant predictor of reading achievement (Durgaiah, 2016, Kizilet, 2017, Schmidt \& Retelsdorf, 2016).

Draper, Barksdale-Ladd \& Radencich (2000) indicate that book readers tended to perceive themselves as individuals who hold more positive attitudes toward reading, who read more types of texts, and have a greater variety and a higher intensity of motivations for reading. They also view themselves as better readers than nonbook readers. Rosli, et.al.(2017) clarify that reading habits are calculated as how much a person read, how often they read, when they read and what do they read. Reading can be summarized as a habit that involves books, printed articles and electronic materials. It varies differently of how each material can affect their reading habits.

Hopper (2005) clarifies that today there is a drop in reading habits among the young, with television, mobile phones, computer games, videos, DVDs and all other new and current distractions from the book seen as contributing to this. It is also seen as a fact that there is a gender difference in reading habits, and that girls choose to read more than boys. The development of reading habits in the society is influenced by both the family and school environment. Teachers are the most effective element within the school environment (Tuba, 2017).

The Dramatic Problematizer Model is deeply rooted in critical pedagogy; in process drama; and in task-based language learning (TBL). These are the components that make up the DPM. Hitotuzi (2014) discusses an approach towards critical thinking development in the EFL classroom that is the Dramatic Problematizer Language 
Learning Model (DPM). The DPM focuses on three different classroom instruction tools; Process Drama, Task-Based Learning, and Critical Pedagogy. Therefore, the essential characteristic of the model incorporates a drama-task stage wherein both the teacher and the students work together to construct meaning through process drama in the students' mother tongue.

According to critical pedagogy, one learns by inquiring, inventing and re-inventing collaboratively, taking one's environment into consideration. Thus, the educational process should be dialogic. There should be some sort of respectful, horizontal, teacher-student, student-teacher and student-student relationship. Through TBL, people learn a language by being exposed to and experimenting with it in a non-threatening environment. Thus, learners should be encouraged to move from reproductive to creative language use. In addition, they should be given opportunities to reflect on what they have learned and how well they are doing. Process drama provides contextualized learning, a sense of ownership about one's learning, and opportunities to act out episodes of life and reflect on them. It enhances thinking, collaborative and creative work, and appreciation (Hitotuzi ,2014,Nunan, 2004 , Willis, 1996) .

Bowell and Heap (2001) cited in Hitotuzi (2014) present some guidelines on how to plan a process drama as a pedagogic tool. It based on six principles; theme / learning area (that concerns with the area of human experience that used for exploring learning purposes); context (refers to the special circumstances created by the drama for the exploration of the theme); roles (deals with the assignment of roles to the students and the teacher .Thus, through role-play, students learn to work cooperatively and to live in society) ; frame (refers to the degree of 
these roles in terms of space, time or emotional involvement) ; sign (includes the set of components that used to make sense of the drama, such as oral or written texts, sounds, images and objects) and strategies (relates to how the process drama will be carried out, always bearing in mind the purpose of each strategy).

Hitotuzi (2014) clarifies that there are many strategies that can be used to help students to go through any curricular component in case of using process drama as learning tool in classroom. These strategies include improvisation; research; group discussions; teacher in role; writing in role; reading in role; rehearsal; script production; reflection and audience in role. Piazzoli (2014) states that process drama does not focus on a product (a final performance), but includes an extended dramatic exploration. It starts from a pre-text that builds up through a series of interlinked episodes, or scenic units, and sustain in a reflection phase. Thus, process drama is not based on a predetermined script, and does not involve an external audience; rather, the participants are simultaneously actors, directors and spectators.

Fransen (2003) indicates that process drama is a form of drama that is designed for the benefit of participants and not for performance. Process drama allows students to use what is comfortable for them in order to find their own style. It is based on improvisation and led by a trained leader. It is more of an exploration of possible problems and their solutions using episodes. It can be defined as a type of episodic drama that consists of segments called episodes. The episodes, while related to the whole picture, may or may not be chronologically linear. They are explorations of the various aspects of the general topic involved. A facilitator, who often is a participant in the drama, leads these explorations .Also, Hertzberg (2001) clarifies that process drama can be used to 
help students interpret and communicate the meanings of themes in narrative texts.

Process drama helps to develop creativity and inventiveness and curiosity. It teaches students to question and develop self-perception and visualization. It improves the ability to think critically, social growth and the ability to work cooperatively with others and enhances communication skills. Thus, using process drama in reading process can help elicit empathy and understanding for the characters involved in the story. This can lead to better student analysis of character and plot development (Annarella, 2000).

Donnery (2013) described process drama as drama that occurs without a formal audience and the participants are also the audience. In addition, Bowell and Heap (2001) cited in Donnery (2013) describe it as the genre in which performance to an external audience is absent but presentation to the internal audience is essential. Thus, the teacher and students produce and engage with the drama to develop meaning, relying on improvisation and reflection for a deepening understanding of the topic. In addition , Jurinović (2016) provides several characteristics of process drama such as; participation of all the participants; the teacher actively participates in the process itself; absence of an external audience; it is composed of episodes and it is organized in stages composed of dramatic plays and nondramatic episodes enabled by getting out of role.

In addition to process drama, one of the approaches proposed to respond to learners' communicative needs was TBL, whose aim is to develop students' ability to communicate. Task-Based Language Teaching (TBLT) is considered as one of the main approaches to language learning and teaching. Tasks 
are defined in terms of what the learners will do in class rather than in the world outside the classroom. Thus, the pedagogical task is a piece of classroom work that involves learners in comprehending, manipulating, producing or interacting in the target language while their attention is focused on mobilizing their grammatical knowledge in order to express meaning, and in which the intention is to convey meaning rather than to manipulate form. The task should also have a sense of completeness, being able to stand alone as a communicative act in its own right with a beginning, middle and an end. As a result, the tasks involve communicative language use in which the user's attention is focused on meaning rather than grammatical form (Campo, 2016, Nunan, 2004).

Task-Based Language provides students with a learning context that requires the use of the target language through communicative tasks, understanding task to be a goal-oriented communicative activity with a specific outcome, where the emphasis is on exchanging meanings not producing specific language form .It is a communicative approach widely applied in settings where English has been taught as a foreign language (EFL). It has been useful to improve learners' communication skills (Pérez, 2016, Willis, 1996).

Task-based language teaching (TBLT) is a realization of communicative language teaching. It is considered the strong version of CLT, as tasks provide the foundation for an entire language program. It characterizes by the following features: major focus on authentic and realworld tasks, choice of linguistic resources by learners, and a clearly defined non-linguistic outcome .It originates from cognitive approach to language learning and psycholinguistics (Nodoushan, 2007, Rahimpour \& Safarie, 2011, Rubin, 2015). 
Nunan (2004) presents seven principles for task-based language teaching. Scaffolding where Lessons and materials should provide supporting frameworks within which the learning takes place. At the beginning of the learning process, learners should not be expected to produce language that has not been introduced either explicitly or implicitly. Task dependency where within a lesson; one task should grow out of, and build upon, the ones that have gone before. Recycling language maximizes opportunities for learning and activates learning principle. Active learning where learners learn by actively using the language they are learning. In integration, learners should be taught in ways that make clear the relationships between linguistic form, communicative function and semantic meaning. In addition, in reproduction to creation learners should be encouraged to move from reproductive to creative language use. In reflection, learners should be given opportunities to reflect on what they have learned and how well they are doing.

Task-based language teaching has been considered as a manifestation of CLT and has emerged as a major point of language teaching practice. In task-based language teaching, the focus is on the completion of the task. Thus, tasks are usually performed in pairs or small groups so they provide opportunities for interaction and for the learners' active use of the language. To complete the task successfully, the focus is on understanding and communicating meanings. All tasks must have a measurable outcome. An outcome that is intrinsically engaging is more likely to develop and maintain learners' intrinsic motivation (Huang, 2010).

Pierson (2015) \& Rashid, Watson \& Cunningham (2017) clarify that Task-based Language Learning (TBLL) is characterized by the use of content oriented activities, the provision of supportive feedback and consideration of 
linguistic forms in the context of actual language use. This approach promotes meaningful use of target language and communicative competence rather than mastery of discrete skills. It encourages the meaningful use of the target language through communicative tasks. Also, it enhances students' motivation to learn the language. Thus, in their study, Tang, Chiou \& Jarsaillon (2015) described the task as it required participants to read a text of the textbook, Google relevant information through both collaborative and individual work, and then produce an oral text for communicative purposes. In addition, Nunan (1996) defined task as a piece of classroom work that involves learners in comprehending, manipulating, producing or interacting in language while their attention is essentially focused on meaning rather than form.

Willis (1996) conducted a framework for task-based learning. He offers teachers a practical guide for conducting tasks in the classroom. This framework consists of three phases: the pre-task phase, the task cycle, and language focus. At the pre-task phase, the teacher highlights useful words and phrases, helps students understand directions for the task, and prepares them for the task. The task cycle includes three components: task: students work in pairs or small groups and the teacher monitors from a distance; planning: students prepare to report to the whole class orally or in writing how they did the task and what they decided or discovered; and report: some groups present their reports to the class or exchange written reports, and then they compare results. During the task cycle, students may also hear a recording or read a text about a similar task and compare how they did it. Finally, the language focus phase can be further divided into two components: analysis: students examine and discuss specific features of the text or transcript of the recording; and practice: teacher conducts practice of new words, phrases, and 
patterns occurring in the data either during or after the analysis.

Anwar \& Arifani (2016) indicate that there are different opinions on tasks but they come into a similar view point that task is a learning activity which guides students for learning performance so that they can process the content of learning. TBLT model focuses the learning activity on meaning in that the teaching action is expected to be able to maximize the existing learning resources in classroom. The goal of this task is to provide authentic functions of learning that contribute to contextual and natural process of learning. Thus, learners are preparing learning tasks to be done in classroom, then reporting the tasks and after that focusing the analysis of learning the meaning behind the tasks to draw on the knowledge naturally and autonomously of the learning materials.

Huang (2010) clarified that in the pre-task stage; students are introduced to the topic and are prepared to cope with the task in a variety of ways. Examples of the pre-task activities are pre-teaching key linguistic items, establishing the task outcome, or performing a similar task .Next, the task cycle offers students the chance to use the language they already know and improve the language under teacher guidance. Students gain fluency and confidence during the task stage. They then improve the language during the planning stage with access to the teacher's help when they need it. The report stage gives students motivation to improve upon the language they use. At the end of the task cycle, students are provided with recordings or texts which provide familiar contexts for the teaching of grammar. The language focus stage leads naturally out of the task cycle. Students have 
opportunities to see grammar rules in use, learn the rules explicitly, and practice the target forms.

Tang, Chiou \& Jarsaillon (2015) investigated how taskbased learning (TBL) developed the verbal competence of Chinese learners of English as a foreign language (EFL) by employing qualitative and quantitative analyses. They compared the impromptu oral presentations on reading texts of 76 intermediate EFL learners. The findings revealed that TBL was effective in fluency, lexical and syntactic complexity, and ineffective in accuracy. The results of the proficiency exams showed that students made significant improvements in reading and little improvement in listening after TBL. Also, Pérez (2016) investigates the effect of tasks on students' spoken interaction in English and motivation towards speaking English in the classroom. The subjects of the research were 35 tenth grade students. The results showed positive influence of tasks in student's' English oral interaction improvement as well as on their motivation towards speaking English in the classroom. Therefore, the effective way to teach a language is by engaging learners in real language use in the classroom through designing tasks-discussions, problems or games that require learners to use the language effectively by themselves (Harji \& Gheitanchian , 2017).

In addition to process drama and task based learning, critical pedagogy (CP) argues that school practices are needed to be informed by a public philosophy that clarifies how to construct ideological and institutional conditions. It is considered as a central concern for the issue of power in the teaching and learning context. It focuses on how and in whose interests knowledge is produced, passed on and view the ideal aims of education as emancipatory (Sajitha \& Nath , 2009). 
Critical pedagogy has brought about positive changes in the field of education by shifting from traditional pedagogy to emancipatory pedagogy. It attempts to move away from teacher and text centered curricula by focusing on students' interests and their situated identities to instill in students a critical mind set to become agents of change. It also emphasizes that the way a student thinks about the world can be changed by the right teaching method. It assumes positive changes in relationship between student and teacher; and the promotion of emancipation (Mahmoodarabi \& Khodabakhsh, 2015).

Bohórquez (2012) indicates that CP is directly concerned with social transformation and educational change. It has caused to reflect on what teachers do every day in school settings: the teaching practices and experiences that teachers manipulate every day with students, colleagues or language classrooms. CP can be considered as an opportunity to evaluate what teachers are doing in classrooms, how they are treating students, how they are implementing methodologies and strategies that really fit in students' contexts, and how teachers and students are integrating into a mutual recreation of knowledge framed in a dialogic pedagogy. Therefore, in their study, Sardabi, Biria \& Golestan (2018) examine the role of a teacher education program informed by the principles of critical pedagogy in influencing novice EFL teachers' professional identity construction.

Critical pedagogy has clarified new roles for teachers, through which they can step beyond classroom concerns. As a result, teachers and students have found new identities and roles. In light of the principles of $\mathrm{CP}$, teachers who were considered as unquestioned authorities have come down from their sacred and safe places to a more friendly and open environment where 
they can negotiate the class procedures, structure, content, grading criteria as well as their own roles in relation to students. Thus, Good students in CP are characterized not as those who would permit themselves to be filled with knowledge (Zadinia, 2011).

The purpose of $\mathrm{CP}$ is to transform educational practices and school by creating an atmosphere where teachers and students develop a common sense through theory, practice and critical analysis and where they can question, discuss the effective relationships between learning, and social transformation. CP is in opposition of the traditional pedagogy. There are differences between $\mathrm{CP}$ and traditional pedagogy in terms of communication between teacher and student. In traditional pedagogy, there is a hierarchical order in educational institutions. Students' critical thinking skills to question what they are presented as reality and the world they live in are not developed (Yilmaz, Altinkurt, \& Ozciftci, 2016).

Critical pedagogy is always in a dynamic process of theorizing practice and practicing theory because it involves an evolving working relationship between theory and practice. It is a concept that argues problems of education and education system itself. The purpose of $C P$ is to signal how questions of audience, voice, power and evaluation actively work to construct schools into an environment where teachers and students can question the relationship between theory and practice, critical analysis and common sense, learning and social change (Kaya \& Kaya, 2017).

In the present research, the researcher focuses on two aspects of the dramatic problematizer language learning model process drama and task based learning in order to improve students' EFL critical reading skills and reading habits. Both aspects are suitable for the research and students as well. 


\section{Context of the Problem}

In light of the researcher's experience in teaching at university level, and the review of related studies such as Abdel Halim (2011) who clarified that fourth-year TEFL majors at Faculty of Education Helwan University have difficulties in critical reading skills. Abdelrasoul (2014) clarifies that critical reading skills are neglected.Yu (2015) clarifies that students complain that they spend a lot of time reading many texts, but they still have many difficulties in reading, not only when they do English tests, but also when they read in normal life. Also, they reveal that they have a little interest in reading English material; they have to prepare for all kinds of tests. Some say they have certain interest in reading English books, such as novels or something, but it is hard for them to read along, not to mention a good understanding.

It can be noted that Abd Kadir, Subki, Jamal \& Ismail (2014) clarify that teachers usually do not emphasize on critical reading skills when teaching reading. They focus more on word attack skills, comprehension skills, and fluency skills. This should not happen because critical reading skills are important for students to learn so that we can prepare them to be better critical readers in life. Students when they leave school either they choose to complete their study or work would face the same challenge that is how to succeed in their life. However, this is not something easy for them to achieve if they do not have the essential critical skills and one of them is the critical reading skills. Therefore, it is necessary for teachers to teach students these critical reading skills because these skills could help them to survive when they leave schools, especially when they join in any program. In order for teachers to produce critical readers, they should expose the students to reading skills (one of the skills is critical reading skills), reading strategies, and metacognitive skills and strategies when they teach reading. 
In their study, Nasrollahi, Krishnasam \& Noor (2015) reveal that students have problems in critical reading skills. Their critical reading development was decreased because there is some concern regarding their poor thinking skills. This may be due to the neglect of critical reading and thinking in the school curriculum. Helping EFL students develop critical reading can be a challenging undertaking. Bedeer (2017) clarified that students encountered difficulties in critical reading skills. Thus, she investigated the effect of a brain based learning program on developing primary stage students' English language critical reading skills.

Hopper (2005) clarifies that today there is a drop in reading habits among the young, with television, mobile phones, computer games, videos, DVDs and all other new and current distractions from the book seen as contributing to this. It is also seen as a fact that there is a gender difference in reading habits, and that girls choose to read more than boys. The development of reading habits in the society is influenced by both the family and school environment. Teachers are the most effective element within the school environment (Tuba, 2017).

To document the problem, the researcher conducted a pilot study on forty students $(\mathrm{N}=40)$ enrolled in third year English section at Faculty of Education, Benha University, Egypt. The pilot study consisted of an EFL critical reading skills test, and reading habits scale. The results of the pilot study reveal that students expressed a sense of boredom related to reading procedures. Most of the reading practices were centered on reading short paragraphs with comprehension, summarizing the texts or answering comprehension and vocabulary questions at the end of reading texts. In general, they prefer texts and activities that would enable them to contribute through expressing themselves and reading texts that would be interesting. According to the reading habits, the pilot study revealed that some students had bad reading habits such as they 
take a time to pronounce the difficult new words, they place their finger beneath the words being read and they look at one word at a time when reading. Thus, there is a need for improving critical reading skills and reading habits among prospective teachers.

\section{Statement of the Problem}

Based on the observation of the researcher, the results of the pilot study and taking into consideration some recommendations of related studies, she noticed students' level in critical reading skill and reading habits is low. In spite the importance of EFL critical reading skills and reading habits, third year students enrolled in English section at Benha Faculty of Education have difficulties in critical reading skills and reading habits. The present research aims at examining the effectiveness of using a dramatic Problematizer language learning model for improving prospective teachers' EFL critical reading skills and reading habits at faculty of Education.

\section{Questions of the Study}

1. What are the features of a Dramatic Problematizer language learning Model for developing EFL prospective teachers' critical reading skills and reading habits?

2. How far is a Dramatic Problematizer language learning Model effective for improving prospective teachers' EFL critical reading skills at Faculty of Education?

3. How far is a Dramatic Problematizer language learning Model effective for improving prospective teachers' EFL reading habits at Faculty of Education?

\section{Review of Related Studies}

It is said that Critical reading (CR) skills are skills that may help students to be able to analyze, synthesize, and evaluate what is read. When teachers expose students to CR skills, they will also make students see the cause and effect or comparing relationships in the text, or adopting 
critical stance toward the text. In other words, when teachers teach CR skills to students they will develop them to be critical thinkers as well because when they do CR it will lead to critical thinking (critical reading will come first before critical thinking. Thus, students need to have fully understood a text where they would analyze, synthesize, and evaluate it, then only they would think critically about the text choose or reject the ideas put forward, agree or disagree with the issues, and most important of all they know the reasons why they do it . CR skills could help students become better readers and thinkers because they will be looking at reading as a process rather than a product (Kadir, Subki, Jamal \& Ismail, 2014).

IÇMEZ (2009) explores the ways in which CR practices can be adapted to traditional EFL reading lessons to increase student motivation. His research aims at identifying the role of three main features of $C R$ courses in increasing motivation, decreased external control, giving an opportunity for the students' own realities in classroom procedures, and optimal arousal. The participants were 24 preparatory students. The instrument was motivation scale. The results show that adapting these three features into EFL reading lessons enhances student motivation. Also, students with high selfefficacy and high English proficiency, traditional reading lessons will lack the essential novelty of CR courses, which is mastering a new skill, within the adaptation.

Abdel Halim (2011) examined the effectiveness of a task-based translation program in improving EFL majors' critical reading skills and political awareness. The participant was a group of fourth-year TEFL majors at Faculty of Education-Helwan University. The instruments were pre- and post-intervention tests and review of written reflections by students and instructor. The results revealed that the project was successful in achieving its aim. 
In his study, Abdelrasoul (2014) aimed at developing the necessary CR skills and social skills of the Egyptian EFL second year preparatory school students, through a proposed program based on using reading circles strategy. The participants were 44 students from Sohag Experimental Preparatory School. The instruments of the study included: a social skills questionnaire (SSQ), a pre/post critical reading skills test (CRST), reading circles role sheets, and reflection sheets. The results revealed that there was statistically significant difference between the mean scores of the study participants in the CR skills test and social skills questionnaire in the pre and postadministrations in favor of the post administration. Also, the use of reading circles strategy increased students' CR skills and social skills.

Albeckay (2014) investigates the lack of CR skills among undergraduate students in Libya, and produces an innovative CR Programme that can be used to develop their skills. The participants were selected from Sebha University and divided into two groups: control and experimental group. Students in the experimental group studied the CR Programme, while the control one was taught by the regular method. The instrument was critical reading test. The results show that CR skills are important for EFL students. They also reveal that critical reading have close links to EFL students' competence in reading comprehension.

Karadağ (2014) explored primary school teachers' views towards CR skills and their perceptions of competence. The participants were 25 fourth year students at the Education Faculty of Adıyaman University. The instruments were semi-structured interviews. The results reveal that the primary school teacher candidates do not consider themselves critically literate and they are 
not aware of CR strategies. In addition, the results show that primary school teachers find the information they have received throughout their teacher education insufficient. The teacher candidates are also found to believe that they lack the skills that critical literacy requires and thus they need more training on this issue.

Khonamri \& Sana'ati (2014) investigate the impacts of dynamic assessment and computer assisted language learning (DACALL) on developing Iranian EFL students' CR. The participants were sixty one student .They were divided into an experimental group and control group. The instrument was critical reading test. The results demonstrated that dynamic assessment and computer assisted language learning are effective in developing CR skills.

Karabay (2015) examines the guiding effects of understanding $\mathrm{CR}$ theories on using external reading strategies such as note-taking and underlining when confronting an ironical literary text. The participants were 60 pre-service teachers and were divided into one control group of 30 teachers and one experimental group of 30 teachers. Two ironical texts were used to collect data from the sample of preservice teachers, one read before the experimental group received instruction in CR theories and the other after such instruction which led to the finding that the entire sample of pre-service teachers mostly summarized and read the texts superficially before they had been exposed to training in CR instruction. After undergoing the critical reading instruction, most of the pre-service teachers in the experimental group who had previously summarized the subject text now rewrote the author's expressions, which is indicative CR. When the notes taken and the expressions underlined by the critical readers were analyzed, it was determined that critical readers 
underlined and took notes of more critical points more and summarized less.

Lestari (2015) investigates the process of teaching CR in an EFL classroom in high school in Indonesia to help students develop their CR. The methodology of the study is a qualitative method in the form of case study design. The data were obtained from field notes, classroom observations, student's journal, group interview, and questionnaire in the end of teaching program. The finding reveals that the teaching of CR may increase students' CR skills. Also, Tanaka (2015) investigates the development of an appropriate pedagogy for CR in the Japanese secondary school context, adopting an action research approach as a methodology.

Balıkçı \& Daloğlu (2016) conducted a case study to observe and investigate the critical reading discourse (CRD) of 27 freshman pre-service teachers of English at the department of foreign language teaching at a state university in Turkey. In addition, the study attempts to answer the question of how the $\mathrm{CR}$ discourse of the students is shaped through feedback, instruction, and time. The written and audio-visual data were collected in the Advanced Reading and Writing I and II courses, which are offered to first-year students in the Foreign Language Education (FLE) department. The results of the data analysis indicate that the critical reading discourse of the freshman pre-service teachers of English involves interpretive, evaluative, and responsive discourse. Evaluative discourse was found to be limited in students' written work and discussions when compared to interpretive and responsive discourse. The students also usually tended to evaluate the content of the texts rather than their form. It was also found that instruction about academic writing fosters critical thinking, but it was not sufficient to encourage $C R$. 
Bedeer (2017) investigated the effect of a brain based learning program on developing the primary stage students' English language critical reading skills. The participants of the present study were 36 of the fifth primary stage students in El-Fayroz School in Cairo. The instruments of the study were: a checklist; a pre-posttest; a scoring scale rubric, an e-survey and an e-portfolio. The results of the study indicated that the proposed program was successful on developing CR skills of the 5th primary stage students.

Sultan, Rofiuddin, Nurhadi \&Priyatni (2017) measure the effect of the critical literacy approach on improving pre-service language teachers' CR skills. The CR skills measured consisted of six levels: interpretation, analysis, inference, evaluation, explanation, and self-regulation. The study was designed as a quasi-experiment that involved 56 pre-service teachers studying at the Indonesian Language Teaching Department. Research data was collected using a CR test. The results of the study indicated that the critical literacy approach had a significant effect on the pre-service language teachers' CR skills. The experimental group achieved better at CR skills and reached higher post-test scores on average. It indicated that the critical literacy approach had a significant effect on CR skills, which include interpretation, analysis, making an inference, evaluation, explanation, and self-regulation.

Ulu, Avşar-Tuncay \& Baş (2017) investigate the relationship between the multimodal literacy of preservice teachers and their perception of self-efficacy in CR. The participants were (337) pre-service teachers. The instruments were Multimodal Literacy Scale and Critical Reading Self-Sufficiency Perception Scale. The results reveal a positive and significant effect on CR self-efficacy 
perception. In his study, Shen (2009) clarifies if computer technology had an impact on EFL college students' reading habits and if students' online reading habits and their demographic variables, such as gender, age, employment status, and online hours were related. 124 valid survey questionnaires were collected from college students at university in southern Taiwan. The results indicated that college EFL students' reading habits changed from paperbased to internet-based reading.

Reading in the 21st century networked society is no longer confined to print reading. The printed publications were the main medium for traditional reading culture. The Internet has come to change the traditional reading habits of the readers. People nowadays tend to rely more on electronic based resources (such as e-books, e-papers, e-journals, e-mails, evideos, e-games, e-images, etc.) than paper based resources (such as books, newspapers, magazines, journals, letters, cards and postcards, pictures, etc.). These electronic sources have, fully or partially, entered in reading habits. Loan (2011) conducted a study to identify the impact of Internet on reading habits of the Net generation students. The student population belongs to the colleges of the Kashmir Valley, Jammu \& Kashmir (India). The survey method was used to conduct the study and questionnaire was used as a data collection tool. The results of study reveal that Internet has increased access to information, use of foreign sources, contacts with worldwide readers and time spent on reading, and have decreased dependence on print sources, contacts with print sources, reading in local languages and reading of books.

In their study, Ahmad, Malik\& Azeem (2014) determine that the computer technology has an impact on university students' reading habit. The participants were 296 learners selected from university in Pakistan. The instrument was reading habits questionnaire. The result 
shows that the college and university students' paper based reading habit changes to internet reading habit.47.9\% of students read online information every day and $28.7 \%$ of them read emails every day.

The activity of reading is the basic tool of learning. University students are groups that are expected to have a high level of reading habit, which is among the individual and social development criteria. Thus, the determination of reading habits of university students is important in both areas they need and in their self-developments throughout their lives. Thus, Erdem (2015) conducted a study to determine the reading habits of students studying at the Ankara University and Erciyes University. The participants were 326 students consisting of 225 students from Ankara University and 101 students from Erciyes University. The instrument was reading habits questionnaire. The results reveal that students at Ankara University and Erciyes University read novels, newspapers and magazines, they enjoy reading literary works, historic, romantic, entertaining, humorous, and psychological genres the most.

Reading habit is a deliberate effort towards understanding and acquiring knowledge. It is also a systematic conscious task of acquiring specific knowledge geared toward a set of standards. Therefore, in their study, Adu-Sarkodee, Asante \& Akussah (2015) investigated the relationship between the use of social media and reading habits focusing on senior high school students in Ghana. They found out that all the constructs of social media thus (Face book, Whatsapps, Yahoomessnger, Skype and Tango) showed a positive significant interrelationship with each other and had effect on reading habits. 
Adnan, Akram \& Akram (2016) explore the factors that are influential in promoting the reading habits of students. The data was collected from 1050 students of three public universities of Punjab with the help of a questionnaire. The study reveals the fact that reading habits are being nurtured from home in which parents play a vital role. Also, teachers nourish this reading habit through their continuous guidance and support. It is recommended that parents and teachers should work in collaboration with one another and create a healthy atmosphere that increases the interest of students in reading. This selfinterest and support of parents and teachers help in promoting the reading habits of students.

In their study Florence, Adesola, Alaba\& Adewumi ( 2017) revealed that the reading habit among Colleges of Education students in Oyo is encouraging. However there is the need for students to read more of novels and articles in order to enhance their vocabulary. Students should make the library their first point of call to get updated from time to time. Also, it was inferred that half of the respondents love reading informational books such as magazine, journals and periodicals. This can be encouraged the more, so that the students will experience all round development in their academics.

Tavsanli \& Kaldirim (2017) examined the reading habits, interests, tendencies of the students studying at the Faculty of Education and analyzed the underlying reason behind their preferences. The participants of the study were 10 students from 5 different fields of Education Faculty, who read books constantly. The instruments were semi-structured interview questions and content analysis method. The results reveal that the most interested book type by the students from Faculty of Education is detected to be novels. Also, students state 
that novels are more exciting, joyful and relaxing besides they feel themselves in the story.

In his study, Tegegne (2017) assesses the reading habits of University students in Ethiopia. The participants were third-year University of Gondar students, who attended their education in 2017/2018. The instruments were questionnaire and interview. The result indicated that their poor reading habit was due to the absence of reading habits, home assignments, watching TV, nonavailability of books, attraction to social media such as Facebook and Twitter, playing sports/ games, increase in the price of books, lack of time, household jobs, the education system, absence of models regarding to reading and lack of early reading experience.

\section{Hypotheses of the Study}

Based on the related studies and research questions, the following hypotheses were formulated:

1. There is a statistically significant difference between the mean score of the experimental group and that of the control group in EFL critical reading skills on the post administration of EFL critical reading skills test in favor of the experimental group.

2. There is a statistically significant difference between the mean score of the experimental group and that of the control group in EFL critical reading sub skills on the post administration of EFL critical reading skills test in favor of the experimental group.

3. There is a statistically significant difference between the mean score of the experimental group and that of the control group in the post administration of reading habit scale in favor of the experimental group.

4. There is a statistically significant difference between the mean score of the experimental group in EFL critical reading skills on the pre and post administration 
of EFL critical reading skills test in favor of post administration.

5. There is a statistically significant difference between the mean score of the experimental group in EFL critical reading sub- skills on the pre and post administration of EFL critical reading skills test in favor of post administration.

6. There is a statistically significant difference between the mean score of the experimental group in the pre and post administration of reading habit scale in favor of post administration.

\section{Methodology}

\section{A. Participants}

The participants of the study consisted of sixty students $(\mathrm{N}=60)$. They were chosen from third students enrolled in English section at Benha Faculty of Education, Egypt. They were divided into two groups; an experimental group $(\mathrm{N}=30)$ and a control group $(\mathrm{N}=30)$. The experimental group was taught through using Dramatic Problematizer Language Learning Model (DPLLM), while the control group was taught by the regular method.

To make sure that both groups were equivalent in the EFL critical reading skills, the EFL critical reading skills test was administered to the control group and the experimental group before implementing the program. Mean, standard deviation and " $\mathrm{t}$ " value of the two groups were computed.

Table 1. " $t$ " test between the control group and the experimental group in the pre-test of the overall EFL critical reading skills

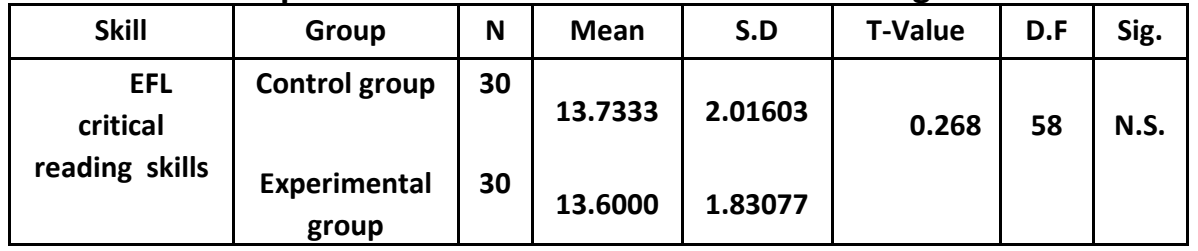


Table (1) indicates that there is no significant difference between the mean scores of the two groups on the overall EFL critical reading skills pre-test, where " $t$ " value is (0.268), which is not significant at (0.01) level of significance. This means that the two groups are equivalent in their EFL critical reading skills.Also, to make sure that both groups were equivalent in reading habits, the EFL reading habits scale was administered to the control group and the experimental group before implementing the program. Mean, standard deviation and " $t$ " value of the two groups were computed.

Table 2. " $\mathrm{t}$ " test between the control group and the experimental group in the pre-administration of the EFL reading habits

\begin{tabular}{|c|c|c|c|c|c|c|c|}
\hline & Group & $\mathbf{N}$ & Mean & S.D & T-Value & D.F & Sig. \\
\hline $\begin{array}{c}\text { Reading } \\
\text { habits }\end{array}$ & $\begin{array}{c}\text { Control } \\
\text { group } \\
\text { Experime } \\
\text { ntal group }\end{array}$ & $\begin{array}{l}30 \\
30\end{array}$ & $\begin{array}{r}65.5000 \\
67.1667\end{array}$ & $\begin{array}{r}21.34891 \\
18.69369\end{array}$ & 0.322 & 58 & N.S. \\
\hline
\end{tabular}

Table (2) indicates that there is no significant difference between the mean scores of the two groups on the EFL reading habits pre- administration, where " $t$ " value is (0.322), which is not significant at (0.01) level of significance. This means that the two groups are equivalent in their EFL reading habits.

\section{B. Design}

The present study is a partially mixed research methodology. It combines both quantitative and qualitative methods of collecting data to help in bridging the gap between quantitative and qualitative research. To conduct the quantitative analysis the pre- post control group design was used. The study participants were tested before and after conducting the program. In addition a qualitative analysis of the students' performance is provided. 


\section{Instruments}

In order to fulfill the purposes of the study, the following instruments were designed.

\section{A.EFL Critical Reading Skills Test}

The EFL critical reading skills test (CRST) was prepared by the researcher to measure EFL critical reading skills among third year students enrolled in English section at Faculty of Education, Benha University, Egypt ( see appendix A).It was used as a pre-posttest (applied before and after implementing the program). The test consisted of (34) questions suitable for students' level and background knowledge (see appendix B). The students are required to read the passages and answer the questions followed them. The time of the EFL critical reading skills test lasted two hours. The researcher calculated time taken by each student finishing the test and the average was found to be two hours. The test was graded by the researcher. The total mark of the test is (34) marks. The questions of the test are multiple choice questions, thus the researcher gave (1) mark for the right answer and (0) for the wrong one.

\section{B. Reading Habits Scale}

The EFL reading habits scale was prepared by the researcher to measure EFL reading habits among third year students enrolled in English section at Faculty of Education, Benha University, Egypt (see appendix C). It was used as a pre-posttest (applied before and after implementing the program). The scale consists of (30) statements with five options for each statement. The options were Never, Rarely, Sometimes, often and Always. The student teacher had to mark his / her response in any one of the options stated as per his / her reading habit. Score allotted to the responses were 1,2,3,4 and 5 . 


\section{C .Semi-Structured Interview}

The interview was constructed to examine the importance of using a program based on dramatic problematizer language learning model among third students enrolled in English section at Benha Faculty of Education, Egypt, and its effectiveness in developing EFL critical reading skills and reading habits. The interview took the format of face to face semi-structured interview. The researcher interviewed students three times; at the beginning of the study, in the middle, and at the end of the study, to gain greater insight on their EFL critical reading skills and reading habits throughout ten weeks. The researcher generally asked the students about their participation in the program. She used open ended questions to avoid responding with yes-no (See Appendix D). Seven students participated in the interview and their responses were video recorded. The interview lasted for one hour. At the beginning of the interview, the researcher greeted the students and asked them to give brief self-introduction as a way to set the goal for the interview. Then, she told them the purpose of the interview and their own roles. If students did not understand any question, she could simplify it or change it .At the end of the interview, the researcher thanked the students for their participation.

\section{Determining the Validity of the Research Instruments}

The EFL critical reading skills test, reading habits scale and the interview were submitted to jury members, they were asked to determine the validity of the instruments in terms of clear instructions, items and its suitability for the students' level. They indicated that the test, the scale and the interview instructions were clear and suitable for students' levels and background knowledge. Therefore, the test, the scale and the interview were considered valid measures of EFL critical reading skills and reading habits 
(Face Validity).To ensure the content validity of the test, scale and interview; they were developed in the light of a systematic and accurate review of literature and previous studies. This accurate and systematic review determined the general form of the test, the scale and the interview questions and methods of correction. Therefore, the content of the test, the scale and the interview was representative of the skills that were intended to be measured. Thus, the test, the scale and the interview were valid and having a content validity.

Determining the Reliability of the Research Instruments

The reliability of the instruments was measured by using the test-retest method. The instruments were administered to a group of third students enrolled in English section at Benha Faculty of Education, Egypt. Then, they were administered to the same group again after two weeks. The Pearson correlation between the two administrations was $(0.88)$ at the 0.01 level. Therefore, the instruments were reliable.

Program based on Dramatic Problematizer language learning Model (DPLLM)

For achieving the purpose of the research, the researcher designed a program based on dramatic problematizer language learning model. After assessing third students' enrolled in English section at Benha Faculty of Education, Egypt critical reading skills and reading habits, the experimental group students were required to attend program based on dramatic problematizer language learning model (See appendix F).

Objectives of the Program based on Dramatic Problematizer language learning Model (DPLLM)

The program aimed at developing EFL critical reading skills and reading habits among third students enrolled in English section at Benha Faculty of Education, Egypt. 
Content of the Program based on Dramatic Problematizer language learning Model (DPLLM)

The topics chosen for the program were selected from books and studies enriched with topics that motivate students. The program contained variety of topics, situations and discussions designed for developing critical reading skills and reading habits. They were suitable for the third students enrolled in English section at Benha Faculty of Education, Egypt such as; Willis (1996); LearningExpress (2004); Tomasek (2009); Hitotuzi (2014); Piazzoli (2014); Erdem (2015); Nasrollahi, Krishnasam \& Noor (2015); Yu (2015); NematTabrizi \& Saber (2016) and Tegegne (2017).

Framework of the Program based on Dramatic Problematizer language learning Model (DPLLM)

The treatment began on Saturday 13th October 2018 and continued through Saturday 15th December 2018. The researcher met the students for three hours per week for ten weeks and also communicated with them via what's' app messages and Facebook page. Week (1) was used for pre-testing and week (10) was used for post testing. Each session was devoted to the following: introduction, objectives, procedures, the role of the researcher and students and finally the performance. During the instructional procedures, different sessions had different learning goals and different methods were applied.

The program was taught to the study participants by the researcher herself. It lasted ten weeks with sixteen instructional sessions and each session lasted for 90 minutes. At the beginning of the program, the researcher introduced to the students what they are going to do. First, she told them about the objectives of the program and what they are supposed to gain as a result of their 
participation in the program (Goal Setting). After that she told them about the importance of critical reading skills and reading habits. Then, she began to introduce the concept of dramatic problematizer language learning model and its importance for language learning and EFL critical reading skills and reading habits.

Following the introduction of the program, the rest of the program were instructional sessions through which the EFL critical reading skills and reading habits were introduced .At the beginning of each session the researcher told students the objectives of the session, the researcher's role, the student's role, the instructional materials that will be used, the activities they will perform and ways of evaluating their progress .At the end of the each session, the researcher gave students some activities related to what they had learned in order to be sure that they mastered the skills in each session (formative evaluation). At the end of the program, the researcher assessed the students' achievement after implementing the program using critical reading skills test and reading habits scale (summative evaluation).

\section{The procedures of the Program}

In this research the researcher used drama process and task based learning as two aspects of Dramatic Problematizer Language Model (DPLLM). Based on Hitotuzi (2014)1 using Dramatic Problematizer Language Model (DPLLM) is divided into seven stages.

1. At the initial dialogue, the researcher provides all the information the students will need to begin the next stage (applying drama process and task based learning).

1 Hitotuzi, N.(2014). The dramatic problematizer model: an approach towards the development of critical thinking in the EFL classroom. The EFL Journal 5 (2), 1-22. 
2. At the drama-task stage and task based learning, both the researcher and the students work together to construct meaning through Process Drama and task based learning in the students' mother tongue.

3. At the reflection stage, the researcher can focus on awareness raising, reflection on the students' own reality, and so help them develop critical reading.

4. At communicative-task stage, the researcher used communicative tasks that encouraged students to participate, collaborate and interact with each other.

5. At the input editing stage, the students involved in the learning process because this activity can be done in collaboration with them as an assignment.

6. The language analysis stage is equivalent to Willis's (1996) focus on form or language focus. The researcher together with the students works reflectively on the structure of the language. At this stage, the researcher can also capitalize work on controlled practice.

7. The final stage is evaluation and feedback. It draws on principles of action research, basically continuous evaluation and adaptation. The researcher and the students reflect on the whole process gone through up to the previous stage, and decide whether or not they need to review any of them.

\section{Findings of the Study}

\section{A . Quantitative Analysis of the Findings}

The findings of the present research are presented in the light of the hypotheses of the research using the Statistical Package for Social Sciences (SPSS). The findings are stated as follows:

\section{Findings of Hypothesis (1)}

The first hypothesis states; there is a statistically significant difference between the mean score of the experimental group and that of the control group in EFL 
critical reading skills on the post administration of EFL critical reading skills test in favor of the experimental group. Table (3) presents the students' mean scores, standard deviations, $t$-value and level of significance of the pre and post assessment of the control group and the experimental group in EFL critical reading skills

Table (3):"t" test between the control group and the experimental group in the post-test of the EFL overall critical reading skills

\begin{tabular}{|c|c|c|c|c|c|c|c|}
\hline Skill & Assessment & $\mathbf{N}$ & Mean & S.D & T-Value & D.F & Sig. \\
\hline EFL Critical & Control group & 30 & 15.2000 & 2.42686 & \multirow[b]{2}{*}{22.872} & \multirow[b]{2}{*}{58} & \multirow[b]{2}{*}{0.01} \\
\hline $\begin{array}{l}\text { Reading } \\
\text { Skills }\end{array}$ & $\begin{array}{l}\text { Experimental } \\
\text { group }\end{array}$ & 30 & 28.7000 & 2.13590 & & & \\
\hline
\end{tabular}

Table (3) shows that the experimental group outperformed the control group in the overall critical reading skills, where "t-value" is (22.872) which is significant at the (0.01) level. Thus, the first hypothesis was verified.

\section{Findings of Hypothesis (2)}

The second hypothesis states: there is a statistically significant difference between the mean score of the experimental group and that of the control group in EFL critical reading sub-skills on the post administration of EFL critical reading skills test in favor of the experimental group. Table (4) presents the students' mean scores, standard deviations, $t$-value and level of significance of the pre and post assessment of the control group and the experimental group in EFL critical reading sub-skills.

\section{The second hypothesis has the following sub-hypotheses}

- There is a statistically significant difference between the mean score of the experimental group and that of the control group in differentiating fact to opinion on the post administration of EFL critical reading skills test in favor of the experimental group. 
- There is a statistically significant difference between the mean score of the experimental group and that of the control group in identifying truth and falsity on the post administration of EFL critical reading skills test in favor of the experimental group.

- There is a statistically significant difference between the mean score of the experimental group and that of the control group in identifying the author's mood, tone, technique on the post administration of EFL critical reading skills test in favor of the experimental group.

- There is a statistically significant difference between the mean score of the experimental group and that of the control group in identifying the author's point of view and purpose on the post administration of EFL critical reading skills test in favor of the experimental group.

- There is a statistically significant difference between the mean score of the experimental group and that of the control group in drawing inferences based on cause/effect relationship on the post administration of EFL critical reading skills test in favor of the experimental group.

- There is a statistically significant difference between the mean score of the experimental group and that of the control group in predicting coming events on the post administration of EFL critical reading skills test in favor of the experimental group.

- There is a statistically significant difference between the mean score of the experimental group and that of the control group in identifying the purpose of the passage on the post administration of EFL critical reading skills test in favor of the experimental group. 
Table (4):"t" test between the mean scores the control group and the experimental group in the post-test of the EFL critical reading Sub-Skills

\begin{tabular}{|c|c|c|c|c|c|c|c|}
\hline Skills & Assessment & $\mathbf{N}$ & Mean & S.D & T-Value & D.F & Sig. \\
\hline \multirow[t]{2}{*}{$\begin{array}{l}\text { Differentiating } \\
\text { fact to opinion }\end{array}$} & $\begin{array}{l}\text { Control } \\
\text { group }\end{array}$ & 30 & 2.9333 & 1.22990 & 10.864 & 58 & \multirow[t]{2}{*}{0.01} \\
\hline & $\begin{array}{l}\text { Experimental } \\
\text { group }\end{array}$ & 30 & 6.0333 & 0.96431 & & & \\
\hline \multirow{2}{*}{$\begin{array}{l}\text { Identifying } \\
\text { truth and } \\
\text { falsity }\end{array}$} & $\begin{array}{l}\text { Control } \\
\text { group }\end{array}$ & 30 & 2.4000 & 1.03724 & 12.145 & 58 & \multirow[t]{2}{*}{0.01} \\
\hline & $\begin{array}{l}\text { Experimental } \\
\text { group }\end{array}$ & 30 & 5.6000 & 1.00344 & & & \\
\hline \multirow{2}{*}{$\begin{array}{c}\text { Identifying the } \\
\text { author's mood, } \\
\text { tone, } \\
\text { technique. }\end{array}$} & $\begin{array}{l}\text { Control } \\
\text { group }\end{array}$ & 30 & 1.7000 & 0.65126 & 12.163 & 58 & \multirow[t]{2}{*}{0.01} \\
\hline & $\begin{array}{l}\text { Experimental } \\
\text { group }\end{array}$ & 30 & 3.5333 & 0.50742 & & & \\
\hline \multirow{2}{*}{$\begin{array}{l}\text { Identifying the } \\
\text { author's point } \\
\text { of view and } \\
\text { purpose }\end{array}$} & $\begin{array}{l}\text { Control } \\
\text { group }\end{array}$ & 30 & 1.6667 & 0.71116 & 8.951 & 58 & \multirow[b]{2}{*}{0.01} \\
\hline & $\begin{array}{l}\text { Experimental } \\
\text { group }\end{array}$ & 30 & 3.3000 & 0.70221 & & & \\
\hline \multirow{2}{*}{$\begin{array}{c}\text { Drawing } \\
\text { inferences } \\
\text { based on } \\
\text { cause/effect } \\
\text { relationship }\end{array}$} & $\begin{array}{l}\text { Control } \\
\text { group }\end{array}$ & 30 & 1.5333 & 0.50742 & 11.285 & 58 & \multirow[t]{2}{*}{0.01} \\
\hline & $\begin{array}{l}\text { Experimental } \\
\text { group }\end{array}$ & 30 & 3.3333 & 0.71116 & & & \\
\hline \multirow[t]{2}{*}{$\begin{array}{c}\text { Predicting } \\
\text { coming events }\end{array}$} & $\begin{array}{l}\text { Control } \\
\text { group }\end{array}$ & 30 & 1.6000 & 0.62146 & 11.068 & 58 & \multirow[t]{2}{*}{0.01} \\
\hline & $\begin{array}{l}\text { Experimental } \\
\text { group }\end{array}$ & 30 & 3.3667 & 0.61495 & & & \\
\hline \multirow{2}{*}{$\begin{array}{c}\text { Identifying the } \\
\text { purpose of the } \\
\text { passage. }\end{array}$} & $\begin{array}{l}\text { Control } \\
\text { group }\end{array}$ & 30 & 1.7333 & 0.69149 & 10.991 & 58 & \multirow[t]{2}{*}{0.01} \\
\hline & $\begin{array}{c}\text { Experimental } \\
\text { group }\end{array}$ & 30 & 3.5333 & 0.57135 & & & \\
\hline
\end{tabular}

Thus, table (4) indicated that the experimental group was much better than their counterparts in EFL critical reading sub-skills where " $t$ " value is (10.864) for EFL differentiating fact to opinion, (12.145) for identifying truth and falsity, (12.163) for identifying the author's mood, tone, technique, (8.951) for identifying the author's point of view and purpose, (11.285) for drawing inferences based on cause/effect relationship,( 11.086) for predicting coming events and (10.991) for identifying the 
purpose of the passage which is significant at the (0.01) level. Therefore, the second hypothesis was confirmed.

\section{Findings of Hypothesis (3)}

The third hypothesis states that; there is a statistically significant difference between the mean score of the control group and experimental group students in reading habits on the post administration of reading habits scale in favor of the experimental group. Table (5) presents the students' mean scores, standard deviations, t-value and level of significance of the pre and post assessment of the control and experimental groups in reading habits.

Table (5):"t" test between the mean scores of the control and experimental group in the post application of the reading habits

\begin{tabular}{|c|c|c|c|c|c|c|c|}
\hline Item & Assessment & $\mathbf{N}$ & Mean & S.D & $\begin{array}{c}\text { T- } \\
\text { Value }\end{array}$ & D.F & Sig. \\
\hline \multirow{2}{*}{$\begin{array}{l}\text { Reading } \\
\text { Habits }\end{array}$} & Control group & 30 & 65.5000 & 21.34891 & \multirow[b]{2}{*}{16.476} & \multirow[b]{2}{*}{58} & \multirow[b]{2}{*}{0.01} \\
\hline & $\begin{array}{c}\text { Experimental } \\
\text { group }\end{array}$ & 30 & 137.0333 & 10.47652 & & & \\
\hline
\end{tabular}

Table (5) indicated that the mean scores of the experimental group students are higher than that of the control group, where "t-value" is (16.476) which is significant at the (0.01) level .Thus, the third hypothesis was supported. Therefore, the third hypothesis was confirmed.

\section{Findings of Hypothesis (4)}

The fourth hypothesis states; there is a statistically significant difference between the mean score of the experimental group in EFL critical reading skills on the pre and post administration of EFL critical reading skills test in favor of post administration. Table (6) presents the students' mean scores, standard deviations, $t$-value and level of significance of the pre and post assessment of the experimental group in EFL critical reading skills. 
Table (6):"t" test between the mean scores of the experimental group in the pre and post administration of the EFL overall critical reading skills

\begin{tabular}{|c|c|c|c|c|c|c|c|}
\hline Skill & $\begin{array}{c}\text { Experimental } \\
\text { group }\end{array}$ & $\mathrm{N}$ & Mean & S.D & $\begin{array}{c}\text { T- } \\
\text { Value }\end{array}$ & D.F & Sig. \\
\hline $\begin{array}{c}\text { EFL Critical } \\
\text { Reading } \\
\text { Skills }\end{array}$ & $\begin{array}{c}\text { Pre- } \\
\text { Administration } \\
\text { post- } \\
\text { Administration }\end{array}$ & 30 & 15.0000 & 1.74198 & 27.604 & 29 & 0.01 \\
\hline
\end{tabular}

Table (6) shows that the experimental group outperformed in the post administration in the overall critical reading skills, where "t-value" is (27.604) which is significant at the (0.01) level .Thus, the fourth hypothesis was verified.

\section{Findings of Hypothesis (5)}

The fifth hypothesis states; there is a statistically significant difference between the mean score of the experimental group in EFL critical reading sub-skills on the pre and post administration of EFL critical reading skills test in favor of post administration. Table (7) presents the students' mean scores, standard deviations, $t$-value and level of significance of the pre and post assessment of the experimental group in EFL critical reading sub-skills.

Thus, table (7) indicated that the experimental group was much better in the post administration than pre administration in EFL critical reading sub-skills where " $t$ " value is (16.000) for EFL differentiating fact to opinion, (12.809) for identifying truth and falsity, (12.318) for identifying the author's mood, tone, technique, (10.172) for identifying the author's point of view and purpose, (9.535) for drawing inferences based on cause/effect relationship,( 11.486) for predicting coming events and (14.994) for identifying the purpose of the passage which is significant at the (0.01) level. Therefore, the fifth hypothesis was confirmed. 
Table (7):"t" test between the mean scores of the experimental group in the pre and post administration of the EFL critical reading sub-skills

\begin{tabular}{|c|c|c|c|c|c|c|c|}
\hline Skills & Assessment & $\mathbf{N}$ & Mean & S.D & $\begin{array}{c}\text { T- } \\
\text { Value }\end{array}$ & D.F & Sig. \\
\hline $\begin{array}{l}\text { Differentiating } \\
\text { fact to opinion }\end{array}$ & $\begin{array}{c}\text { Pre- } \\
\text { Administration } \\
\text { post- } \\
\text { Administration }\end{array}$ & 30 & $\begin{array}{r}2.8333 \\
6.0333\end{array}$ & $\begin{array}{l}0.87428 \\
0.96431\end{array}$ & 16.000 & 29 & 0.01 \\
\hline $\begin{array}{l}\text { Identifying truth } \\
\text { and falsity }\end{array}$ & $\begin{array}{c}\text { Pre- } \\
\text { Administration } \\
\text { post- } \\
\text { Administration }\end{array}$ & 30 & $\begin{array}{l}2.5333 \\
5.6000\end{array}$ & $\begin{array}{l}0.86037 \\
1.00344\end{array}$ & 12.809 & 29 & 0.01 \\
\hline $\begin{array}{l}\text { Identifying the } \\
\text { author's mood, } \\
\text { tone, technique. }\end{array}$ & $\begin{array}{c}\text { Pre- } \\
\text { Administration } \\
\text { post- } \\
\text { Administration }\end{array}$ & 30 & $\begin{array}{l}1.6333 \\
3.5333\end{array}$ & $\begin{array}{l}0.66868 \\
0.50742\end{array}$ & 12.318 & 29 & 0.01 \\
\hline $\begin{array}{l}\text { Identify the } \\
\text { author's point of } \\
\text { view and } \\
\text { purpose }\end{array}$ & $\begin{array}{c}\text { Pre- } \\
\text { Administration } \\
\text { post- } \\
\text { Administration }\end{array}$ & 30 & $\begin{array}{l}1.6000 \\
3.3000\end{array}$ & $\begin{array}{l}0.62146 \\
0.70221\end{array}$ & 10.172 & 29 & 0.01 \\
\hline $\begin{array}{c}\text { Drawing } \\
\text { inferences } \\
\text { based on } \\
\text { cause/effect } \\
\text { relationship }\end{array}$ & $\begin{array}{c}\text { Pre- } \\
\text { Administration } \\
\text { post- } \\
\text { Administration }\end{array}$ & 30 & 3.3333 & $\begin{array}{l}0.68229 \\
0.71116\end{array}$ & 9.535 & 29 & \\
\hline $\begin{array}{c}\text { Predicting } \\
\text { coming events }\end{array}$ & $\begin{array}{c}\text { Pre- } \\
\text { Administration } \\
\text { post- } \\
\text { Administration }\end{array}$ & & $\begin{array}{l}1.5333 \\
3.3667\end{array}$ & $\begin{array}{l}0.62881 \\
0.61495\end{array}$ & 11.486 & 29 & 0.01 \\
\hline $\begin{array}{l}\text { Identifying the } \\
\text { purpose of the } \\
\text { passage }\end{array}$ & $\begin{array}{c}\text { Pre- } \\
\text { Administration } \\
\text { post- } \\
\text { Administration }\end{array}$ & 30 & $\begin{array}{l}1.3667 \\
3.5333\end{array}$ & $\begin{array}{l}0.49013 \\
0.57135\end{array}$ & 14.994 & 29 & \\
\hline
\end{tabular}

\section{Findings of Hypothesis (6)}

The sixth hypothesis states that; there is a statistically significant difference between the mean score of the experimental group students in reading habits on the pre and post administration of reading habits scale in favor of the post administration. Table (8) presents the students' 
mean scores, standard deviations, t-value and level of significance of the pre and post assessment of experimental groups in reading habits.

Table (8):"t" test between the mean scores of the control and experimental group in the post application of the reading habits

\begin{tabular}{|c|c|c|c|c|c|c|c|}
\hline Item & $\begin{array}{c}\text { Experimental } \\
\text { group }\end{array}$ & $\mathrm{N}$ & Mean & S.D & $\begin{array}{c}\text { T- } \\
\text { Value }\end{array}$ & D.F & Sig. \\
\hline $\begin{array}{c}\text { Pre- } \\
\text { Reading }\end{array}$ & $\begin{array}{c}\text { Administration } \\
\text { post- } \\
\text { Administration }\end{array}$ & 30 & $\begin{array}{c}76.1667 \\
137.0333\end{array}$ & 10.47652 & 23.025 & 29 & 0.01 \\
\hline
\end{tabular}

Table (8) indicated that the mean scores of the experimental group students are higher in the post administration than pre administration, where "t-value" is (23.025) which is significant at the (0.01) level .Thus, the sixth hypothesis was supported.

\section{B . Qualitative Analysis of the Findings}

At the beginning of the program, the students were afraid of reading in general and critical reading particularly. They have problems in critical reading and reading habits. Students didn't learn how to critically engage with texts, understand how the texts are part of an intellectual relation and express their opinion about the texts they read. They are accustomed to reading comprehension questions and word attack. They didn't train on how to move beyond reading the text, address questions such as, what was the author's purpose? Who was the intended audience? Who or what was the author responding to? According to the reading habits, students had bad reading habits such as they take a time to pronounce the difficult new words, they place their finger beneath the words being read and they look at one word at a time when reading.

After participating in the program based on dramatic problematizer language learning model, students gained 
more confidence and began to read in a better way. They become able to read critically, evaluate the reading text and clarify the author's purpose. In the interview data, seven students had similar positive reaction towards using dramatic problematizer language learning model, they clarified that in dramatic problematizer model, and everyone is contributing to move forward in a clear direction. Everyone works to achieve common, shared goals. They also worked together, collaborating and cooperating to make progress.

To understand how students perceived the importance of dramatic problematizer model in developing EFL critical reading skills and reading habits, some interview questions were asked. Examples from the researcher's transcripts provided insight into the students' perception about the activities in dramatic problematizer language learning model. Students clarified that their critical reading skills and reading habits were improved because of the various activities that increased their desire to read critically. Therefore, it can be clarified that the steps of dramatic problematizer model included activities and tasks that are effective in improving EFL critical reading skills and reading habits. The students' views in this regard are as follows:

- Student (1): Through participating in the program, I become able to realize the negative and positive aspects of what is being read.

- Student (2): I began to read different genres instead of depending on certain type. I also chose what and who to read, aware of what I read and knew what the writer of the text I read.

- Student (3): As a result of participation, my critical reading skills are developed. I began to be neutral while reading and respect different point of views. 
- Student (4): I have the ability ask myself questions and try to guess what may happen next.

- Student (5): I read the book cover and the first few pages when choosing what I want to read and as a result I stop reading the books that don't attract me.

- Student (6): Through participating in the program, I become able to read a number of different materials.

- Student (7): Through DPLLM, I try to find my popular authors' books to read and benefit from them.

\section{Discussion of the Results}

The primary purpose of the study was to develop EFL critical reading skills and reading habits among third year students enrolled in English section at Faculty of Education, Benha University Egypt through using a program based on dramatic problematizer language learning model. The program included variety of tasks and activities for helping students to enhance their EFL critical reading skills and reading habits. The results of the study revealed that the program proved to be statistically and educationally significant in developing EFL critical reading skills and reading habits among third year students enrolled in English section at Faculty of Education, Benha University Egypt.

Through participating in the program, students express their opinion as readers of the texts through class discussions following reading the texts. First of all, they have a class discussion on what kind of texts they would like to read. The students were also encouraged to express their opinions both as individuals and as EFL learners on the texts both before and after reading a text. These results are consistent with IÇMEZ (2009). In addition ,students' critical reading skills are improved. They became able to judge the reading material and not accept all the information they found in the text. As a result, they 
had positive attitudes towards the reading text while reading it and became neutral while reading .They also read different types of texts and thought from different perspectives. They began to think while reading and being aware of what is being read. They also evaluated the reading text with all its aspects. These results are consistent with Karadağ (2014).

Students' reading habits enhanced. Students began to read about various topics not focusing on certain ones. They used what they already know to help them understand what they read (making a link between previous knowledge and new one) and they shared titles of the books with their friends to encourage them to read more and more. The students are very interested in reading and willing to spend time on reading different books for many times. According to the type of reading materials, students read print and online materials. Therefore, reading habit is considered an important mean to gain information and knowledge, development of cognitive abilities, personal traits and understanding of an individual as well. These results are consistent with Adnan, Akram \& Akram (2016) \& Hopper (2005).

\section{Conclusions}

The results of the study revealed that the participants' EFL critical reading skills and reading habits developed after the implementation of dramatic problematizer language learning model. The effectiveness of dramatic problematizer model language learning may be due to the various activities, tasks and strategies the researcher presented to the students. Through the implementation of dramatic problematizer language learning model, major findings of the study were considered as the students' chances for learning by doing and experiences, their belief for better learning and development of learning skills with 
fun and enjoyment. Moreover, their emphasis on certain personal developments such as thinking, self-confidence, communication skills and team spirit and their consideration of instructor as a guide for learning. When considering the advantages and positive outcomes of the program, it is clear that the program proved developing critical reading skills and reading habits among prospective teachers. Thus, dramatic problematizer language learning model was more successful than the traditional teaching.

\section{Recommendations of the Study}

In the light of previous results, the following recommendations could be presented:

- Teachers of English language should be trained on using dramatic problematizer language learning model, while teaching English to their students in different educational stages.

- English language teacher should emphasize the development of the students' critical reading skills in the early educational stages to develop them in the following stages.

- Curriculum designers should make use of dramatic problematizer language learning model when designing English language courses and overcoming any teaching or learning problems.

- The faculty of Education can arrange reading- based conferences and discussions that help students' teachers develop their reading interests.

- Reading clubs should be established in the faculty of Education to enhance students' critical reading and reading habits. 


\section{Suggestions for Further Research}

Based on the findings of the present research, the following implications for further research are suggested:-

- Investigating the effectiveness of dramatic problematizer language learning model in English language learning among students teachers at University level.

- Critical reading should be a part of curriculum from the beginning of primary education to higher education programs.

- Clarifying the influence of dramatic problematizer language learning model on other language skills such as listening and speaking.

- Investigating the effectiveness of dramatic problematizer language learning model in enhancing students' critical writing skills.

- Clarifying the effect of using other strategies on developing students' EFL critical reading skills and reading habits.

\section{References}

- Abd Kadir, N. , Subki, R. N. S., Jamal, F. H. A., \& Ismail, J. (2014). The importance of teaching critical reading skills in a Malaysian reading classroom. In The 2014 WEI International Academic Conference Proceedings. (pp. 208-219). Austria: Vienna.

- Abdel Halim, S.M. (2011). Improving EFL majors' critical reading skills and political awareness: A proposed translation program. International Journal of Educational Research 50, 336-348.

- Abdelrasoul, M.M.(2014).Using Reading Circles Strategy for Developing Preparatory Students' Critical Reading Skills and Social Skills. Unpublished master thesis, faculty of Education , Ain Sham University , Egypt.

- Abdul Rahman, Z.A.A.(2013). The Use of Cohesive Devices in Descriptive Writing by Omani Student Teachers. SAGE Open, 1, 110. 
- Adnan, A., Akram, F.\& Akram, A.(2016). Identification of Factors Promoting Reading Habits of Students: A Case Study on Pakistan.Research on Humanities and Social Sciences, 6(17), 5662.

- $\quad$ Adu-Sarkodee, R., Asante,E. \& Akussah,M. (2015).Relationship between Uses of Social Media on Reading Habits: Evidence from Senior High Students in Ghana. Information and Knowledge Management ,5(11),26-32.

- Ahmad ,H.I., Malik, K.\& Azeem, M.(2014). A Study of Reading Habit and Computer Technology Effect on Student in Pakistan. Journal of Education and Literature, 1(1), 9-19.

- Albeckay, E.M.(2014). Developing Reading Skills through Critical Reading Programme amongst Undergraduate EFL Students in Libya. Procedia - Social and Behavioral Sciences 123, 175- 181.

- Annarella,L. A. (2000). Using Creative Drama in the Writing and Reading Process. (An available online Full text No.ED. 445 358).

Anuar, N.\& Sidhu, G.K.(2017). Critical reading skills: A Survey of Postgraduate Students' Perspective of Critical Reading. Pertanika J. Soc. Sci. \& Hum, 25 (S),163 - 172.

- Anwar,K. \& Arifani, Y.(2016). Task Based Language Teaching: Development of CALL. International Education Studies, 9( 6), 168183.

- $\quad$ Babu ,M.R.\& Durgaiah,P.(2016) Reading Habits among Student Teachers In Relation To Their Age, Gender and Management. The International Journal of Indian Psychology 3( 4),170-176.

- Balıkçı, G.,\& Daloğlu, A.(2016).Critical Reading Discourse of PreService English Teachers in Turkey. The Electronic Journal for English as a Second Language, 20 (1), 1-19.

- Bedeer, F.A. M.(2017). The Effect of A Brain - Based Learning Program on Developing Primary Stage Students' English Language Critical Reading Skills. Unpublished doctoral dissertation . Ain Shams University, Egypt.

- Bohórquez, Y.S. (2012). On Rethinking Our Classrooms: A Critical Pedagogy View. HOW, A Colombian Journal for Teachers of English, 19, 194-208.

- Bowell , P. \& Heap,B. (2001) cited in Donnery, E. M. D. (2013). JoHa-Kyu: enticement - crux -consolidation. From study to learning: Process drama projects in the Japanese English language 
university classroom. Unpublished doctoral dissertation, University College Cork.

- Bowell, P. \& Heap, B.S. (2001) cited in Hitotuzi, N.(2014). The dramatic problematizer model: an approach towards the development of critical thinking in the EFL classroom. The EFL Journal 5 (2), 1-22.

- Bulgurcuoglu, A.N.(2016).Relationship between critical thinking levels and attitudes towards reading habits among pre-service physical education teachers. Educational Research and Reviews, 11(8), 708-712.

- Campo, A.C.B. (2016). Improving 10th Graders' English Communicative Competence through the Implementation of the Task-Based Learning Approach. Profile Issues in Teachers' Professional Development, 18(2), 95-110.

- Chiang, I.N.(2016).Reading Habits, Language Learning Achievements and Principles for Deep Knowledge. Linguistics and Literature Studies 4(3), 203-212.

- Damaianti ,V.S. , Damaianti,L.F.\& Mulyati, Y.(2017). Cultural Literacy Based Critical Reading Teaching Material with Active Reader Strategy for Junior High School. International Journal of Evaluation and Research in Education (IJERE),6(4),312-317 .

- Donnery, E. M. D. (2013). Jo-Ha-Kyu: enticement - crux consolidation. From study to learning: Process drama projects in the Japanese English language university classroom. Unpublished doctoral dissertation, University College Cork.

- Draper, M. C., Barksdale-Ladd, M., \& Radencich, M. C. (2000). Reading and Writing Habits of Preservice Teachers. Reading Horizons,40 (3), 185-203.

- Durgaiah, P.(2016). Reading habits among student teachers with respect to gender and qualification. International Journal for educational Research studies, II(VIII), 655-661.

- Erdem, A.(2015). A research on reading habits of university students:(Sample of Ankara University and Erciyes University). Procedia - Social and Behavioral Sciences 174 , 3983 - 3990

- Erkan, S.S.S., Dağal,A.B. \& Tezcan, Ö. (2016).Evaluation of Reading Habits of Teacher Candidates: Study of Scale Development.Journal of Education and Training Studies, 4(1), 101-108. 
- Florence, F.O., Adesola, O.A., Alaba, H.B. \& Adewumi, O.M.(2017). A Survey on the Reading Habits among Colleges of Education Students in the Information Age. Journal of Education and Practice, 8(8),106-110.

- Fransen, W.J.(2003). Process drama and creative problem solving: an integrated approach. Unpublished doctoral dissertation, Texas Tech University

- Harji, M.B., \& Gheitanchian, M.(2017). Effects of Multimedia Task-Based Teaching and Learning Approach on EFL Learners' Accuracy, Fluency and Complexity of Oral Production .TOJET: The Turkish Online Journal of Educational Technology ,16 (2),25-34.

- Haromi,F.A.( 2014). Teaching through Appraisal: Developing Critical Reading in Iranian EFL Learners.Procedia - Social and Behavioral Sciences, $98,127-136$

- Hertzberg, M.(2001). Using Drama To Enhance the Reading of Narrative Texts. (An available online Full text No.ED. 456 485).

- Hitotuzi, N.(2014). The dramatic problematizer model: an approach towards the development of critical thinking in the EFL classroom. The EFL Journal 5 (2), 1-22.

- Hopper, R. (2005). What are teenagers reading? Adolescent fiction reading habits and reading choices. Literacy ,39 (3), 113-120.

- Huang ,J.(2010). Grammar Instruction for Adult English Language Learners: A Task-Based Learning Framework. Journal of Adult Education Information Series, 39 (1), 29-37.

- Hudson, T. (2007) cited in Kadir, N. A., Subki, R. N. S., Jamal, F. H. A., \& Ismail, J. (2014). The importance of teaching critical reading skills in a Malaysian reading classroom. In The $2014 \mathrm{WEI}$ International Academic Conference Proceedings. (pp. 208-219). Austria: Vienna.

- Hudson, T.(2007) cited in Tanaka ,M.(2015).Appropriate Pedagogy for Critical Reading in English in the Japanese Secondary School Context: An Action Research Investigation. Unpublished doctoral dissertation , University of Warwick.

- IÇMEZ, S. (2009). Motivation and critical reading in EFL classrooms: a case of ELT preparatory students. Journal of Theory and Practice in Education, 5(2), 123-147.

- Jurinović, M.R.(2016). Process Drama as a Form of Cooperative Learning. Croatian Journal of Education , 18(2), 239-253. 
- Karabay, A.(2015). The guiding effects of a critical reading program on the use of external reading strategies when confronting an ironical text. Educational Research and Reviews,10 (16), pp. 2296-2304.

- Karaca, P.O. \& Oguz , F.G.(2017). A Conceptual Evaluation on Critical Reading.IOSR Journal Of Humanities And Social Science (IOSR-JHSS) ,22(12), 38-41.

- Karadağ, R.(2014). Primary school teacher candidates' views towards critical reading skills and perceptions of their competence.Procedia Social and Behavioral Sciences 152,889 - 896.

- Kaya ,Ç. \& Kaya, S.(2017). Prospective Teachers' Educational Beliefs and Their Views about the Principles of Critical Pedagogy .Journal of Education and Learning, 6( 4), 181-190.

- Khonamri,F.\& Sana'ati,M.K. (2014). The Impacts of Dynamic Assessment and CALL on Critical Reading: An Interventionist Approach. Procedia - Social and Behavioral Sciences, 98,982 - 989.

- Kizilet, A. (2017). Investigation of critical thinking attitudes and reading habits of teacher candidates. Educational Research and Reviews, 12(6), 323-328.

- Küçükoğlu, H.(2013).The interface between EFL teachers' selfefficacy concerning critical reading comprehension and some select variablesProcedia - Social and Behavioral Sciences, 70 , $1646-1650$.

- Lestari, Z.W.(2015). The teaching of critical reading in an EFL classroom. International Journal of Social Sciences, 1(1), 519-530.

- Loan, F.A.(2011).Impact of internet on reading habits of the net generation college students. International Journal of Digital Library Services ,1(2),43- 48.

- Mahmoodarabi, M.\& Khodabakhsh, M.R.(2015). Critical Pedagogy: EFL Teachers' Views, Experience and Academic Degrees. English Language Teaching, 8( 6),100-110.

- Maltepe, S. (2016). An analysis of the critical reading levels of preservice Turkish and literature teachers. Eurasian Journal of Educational Research, 63, 169-184, http://dx.doi.org/ 10.14689/ejer.2016.63.10.

- Nasrollahi, M.A., Krishnasam, P.K.N. \& Noor,N.M.( 2015). Process of Implementing Critical Reading Strategies in an Iranian EFL Classroom: An Action Research. International Education Studies, 8(1), 9-16. 
- NematTabrizi,A.R.\& Saber, M.A.(2016). The Effect of Critical Reading Strategies on EFL Learners' Recall and Retention of Collocations. International Journal of Education \& Literacy Studies, 4 (4), 30-37.

- Nodoushan, M.A.S.(2007). A framework for task - oriented language instruction. I-manager's Journal on School Educational Technology, 3(3), 5-16.

- Nunan, D.(2004). Task-based language teaching. Cambridge: Cambridge University Press.

- Oguz, E.,Yıldız, A., \& Hayırsever, F. (2009). Assessing Reading Habits of Future Classroom Teachers in the Context of Their Socio- Demographic Features. World Academy of Science, Engineering and Technology 31, 1004-1007

- Owusu-Acheaw, M.(2014). Reading Habits Among Students and its Effect on Academic Performance: A Study of Students of Koforidua Polytechnic. Library Philosophy and Practice (ejournal). 1130.http://digitalcommons.unl.edu/libphilprac/1130.

- Palani,K.K.(2012).Promoting reading habits and creating literate society. International Refereed Research Journal, III (2),90-94.

- Pérez, N.P.C.(2016) Effects of Tasks on Spoken Interaction and Motivation in English Language Learners.Gist Education and Learning Research Journal, (13),34-55.

- Piazzoli, E.C.(2014). Engagement as perception-in-action in process drama for teaching and learning Italian as a second language. International Journal of Language Studies, 8(2),91-116.

- Pierson, S. J. (2015). Bridges to Swaziland: Using task-based learning and computer-mediated instruction to improve English language teaching and learning. Teaching English with Technology, 15(2), 105-119.

- Rahimpour, M. \& Safarie, M.(2011). The Effects of On-line and Pre-task Planning on Descriptive Writing of Iranian EFL Learners. International Journal of English Linguistics, 1(2), 274-280.

- Rashid, S., Watson, K., \& Cunningham, U. (2017). Task-based language teaching with smartphones: A case study in Pakistan. Teachers and Curriculum, 17(2), 33-40.

- Rosli, N.A.; Razali, N.F.; Zamil, Z.U.A.; Noor, S.N.F.M. \& Baharuddin, M.F.(2017). The Determination of Reading Habits 
among Students: A Concept. International Journal of Academic Research in Business and Social Sciences, 7(12), 791-798.

- Rubin, J.(2015). Using Goal Setting and Task Analysis to Enhance Task-Based Language Learning and Teaching. ( An online Eric database full text No.ED.456485).

- Sajitha,P.S. \& Nath ,K.B.( 2009). Research perspectives in issue based curriculum and critical pedagogy. ( An online Eric database full text No.ED.507656).

- Sardabi, N., Biria, R., \& Golestan, A. A. (2018). Reshaping Teacher Professional Identity through Critical Pedagogy-Informed Teacher Education. International Journal of Instruction, 11(3), 617-634.

- Schmidt, F.T.C.\& Retelsdorf, J.(2016). A New Measure of Reading Habit: Going Beyond Behavioral Frequency .Frontiers in Psychology , 7,1-8.

- Shen, L.B.(2009). Computer Technology and College Students' Reading Habits.CHIA-NAN ANNUAL BULLETIN, 32, 559-572

- Siebert, H. (2008) cited in Adnan, A., Akram, F.\& Akram, A.(2016). Identification of Factors Promoting Reading Habits of Students: A Case Study on Pakistan.Research on Humanities and Social Sciences, 6(17), 56-62.

- Sriwantaneeyakul, S.(2018). Critical Reading Skills and Translation Ability of Thai EFL Students:Pragmatic, Syntactic, and Semantic Aspects. English Language Teaching, 11( 4),1-14.

- Sultan; Rofiuddin, A.; Nurhadi \& Priyatni, E. T.(2017).The Effect of the Critical Literacy Approach onPre-service Language Teachers' Critical Reading Skills.Eurasian Journal of Educational Research 71,159-174

- Tanaka ,M.(2015).Appropriate Pedagogy for Critical Reading in English in the Japanese Secondary School Context: An Action Research Investigation. Unpublished doctoral dissertation , University of Warwick.

- Tang ,H. ,Chiou, J.S. \& Jarsaillon,O. (2015). Efficacy of Task-Based Learning in a Chinese EFL Classroom: A Case Study. English Language Teaching, 8 ( 5),168-176.

- Tavsanli, O. F., \& Kaldirim, A. (2017). Examining the reading habits, interests, tendencies of the students studying at the faculty of education and analyzing the underlying reason behind 
their preferences. European Journal of Educational Research, 6(2), 145-156.

- Tegegne, M.T.(2017). Reading habits of students in higher institutions: reflections from Ethiopia. Journal of Community Positive Practices, XVII(3) , 67-77

- Tomasek, T.(2009). Critical Reading: Using Reading Prompts to Promote Active Engagement with Text. International Journal of Teaching and Learning in Higher Education , 21, (1), 127-132.

- Tuba, S.B.(2017). A study on reading habits of social studies and history teachers in Turkey. Educational Research and Reviews, 12 (10), 569-582.

- Ulu,H., Avşar-Tuncay,A. \& Baş, Ö.(2017). The Relationship between Multimodal Literacy of Pre-Service Teachers and Their Perception of Self-Efficacy in Critical Reading.Journal of Education and Training Studies, 5(12), 85-91.

- Wallace, C. (1998). Critical language Awareness in foreign language classroom .Unpublished doctoral dissertation. Institute of Education, University of London.

- Willis, J. (1996). A framework for task-based learning. London: Longman.

- Yilmaz, K., Altinkurt, Y., \& Ozciftci, E. (2016). The relationship between teachers' views about the cultural values and critical pedagogy. Eurasian Journal of Educational Research, 66, 191-210.

- Yu, J.(2015). Analysis of Critical Reading Strategies and Its Effect on College English Reading. Theory and Practice in Language Studies, 5( 1), 134-138.

- Zabihi,R .\& Pordel, M.(2011). An Investigation of Critical Reading in Reading Textbooks: A Qualitative Analysis. International Education Studies, 4(3), 80-87.

- Zadinia,M.(2011). Incorporating the Principles of Critical Pedagogy into a Teacher Efficacy Measure. English Language Teaching , 4(2),138-150. 